\title{
The end of humanitarian
}

\section{intervention: Evaluation of the}

\section{African Union's right of intervention}

\author{
Dan Kuwali ${ }^{\star}$
}

\section{Abstract}

The right to intervene under the AU Act is a radical departure from, and in stark contrast with, the principle of State sovereignty and non-intervention, the very cornerstones of the erstwhile OAU. Although intervention has traditionally been opposed by African States and regarded as imperialism; under the AU Act, AU Member States have themselves accepted sovereignty not as a shield but as a responsibility where the $\mathrm{AU}$ has the right to intervene to save lives from mass atrocity crimes. Today, human rights are not a purely domestic concern and sovereignty cannot shield repressive States. Thus, if a State is unable or unwilling to protect its people the responsibility falls on other States. What is certain is that the thresholds for intervention are serious crimes under international law, which are subject to universal jurisdiction. Therefore, Article 4(h) can be viewed as providing for statutory intervention in form of enforcement action by consent to prevent or halt mass atrocity crimes. However, yet to be answered is how to reconcile the $\mathrm{AU}$ right to intervene with the provisions of the UN Charter, especially where the AU exercises military intervention. Nonetheless, the AU

* Dan Kuwali is Fellow, Carr Center for Human Rights Policy, Harvard University; Doctoral Candidate, Lund University/Raoul Wallenberg Institute; Deputy Director of Legal Services Malawi Defence Force and Correspondent, Yearbook of International Humanitarian Law. 
should reduce the need for costly intervention and focus more on preventive strategies.

\section{Introduction}

The genesis to the discussions of emerging African capacities to protect populations at risk of grave human rights violations is the failure of the international community to respond appropriately to tragedies such as the collapse of the Somali state, genocide in Rwanda, the protracted conflict in the Democratic Republic of the Congo (DRC) and the current crisis in Darfur. Commentators indicate that the inability or unwillingness of the United Nations (UN) and the international community as a whole to protect Africans in these situations 'shattered illusions of a post-Cold War peace dividend and prompted many to search for new protection mechanisms' (Powell \& Baranyi 2005:2).

The question Africa has grappled with is how African States can best address the circumstances that might warrant external intervention in internal situations. However, the broader international community has focused on the particular question of whether humanitarian emergencies may provide an additional exception to the prohibition in international law of the use of force by states. This dichotomy challenges the normative framework on the issue of intervention. The debate about the controversial notion of humanitarian intervention is about the manifest failure of the international community to respond in a coherent and effective manner to the humanitarian crises that have unfolded in Somalia, Rwanda, Bosnia, Kosovo, Darfur and so forth.

For Harhoff, 'if the assumption is accepted that international law is currently incapable of providing a clear legal position in respect of the lawfulness of humanitarian interventions', which seems to be the correct assumption, 'the question then remains what international legal theory can or should do to bring about clarification of the law' (Harhoff 2001:107; cf Cassese 1999). However, the lacuna for a clear position on humanitarian intervention should not be seen as a shortcoming in international law, but rather as an assertion of the fact that international law evolves from the challenges which emerge out of contentions and conflicts between states (Harhoff 2001:106-108). Yet, the 1991 unauthorised 


\section{The end of humanitarian intervention}

intervention in Iraq led by the United States (US) and the United Kingdom (UK), the Economic Community of West African States (ECOWAS) intervention in Liberia and the 1999 North Atlantic Trade Organisation (NATO) intervention in Kosovo are part of a larger trend that have seen states give increased weight to human rights and humanitarian norms as matters of international concern. As a result, the Security Council may now characterise these concerns as threats to international peace liable to enforcement measures under Chapter VII of the UN Charter (Kaplan 2000:25-27).

The genocide in Rwanda and NATO's action in Kosovo lifted the debate of humanitarian intervention to the top of the international community's agenda, exposing the need to develop a more comprehensive position on the lawfulness of such interventions in international law. Against this backdrop, the African Union (AU) provides for unprecedented powers of intervention in a Member State as an exception to the principle of state sovereignty. Yet, the normative status of the doctrine of humanitarian intervention is still a grey area and a contentious issue in international law. The pertinent part of Article 4(h) provides for 'the right of the $[\mathrm{AU}]$ to intervene in a Member State pursuant to a decision of the Assembly in respect of grave circumstances, namely: war crimes, genocide and crimes against humanity'. The AU right to intervene under Article 4(h) and (j) of the Constitutive Act of the African Union (AU Act), like the doctrine of humanitarian intervention, presupposes an exception to the general prohibition on the use of force in international relations. For such intervention to have a genuinely humanitarian character, the intervening states must not act out of any element of self-interest and therefore the beneficiaries of intervention must not be nationals of the intervening state (Sunga 2006:44-45). This progressive mandate reflects the AU's acknowledgement of the 'responsibility to protect' (R2P) - the universal notion that the international community has a duty to intervene to protect a population from mass atrocity crimes if governments abdicate their sovereign responsibilities (UN 2005:para 138-139).

While it is seemingly sound that protection of human rights of citizens should prevail over state sovereignty, the problem was, and still is, that challenging the notion of sovereignty also amounts to questioning the cornerstones of the UN Charter in Articles 2(1), 2(4) and 2(7) that guarantee, inter alia, territorial 


\section{Dan Kuwali}

sovereignty of all Member States and outlaw war. The right of intervention faces challenges ranging from violations of state sovereignty to questions of national interest and political will and the violations of human rights that so often accompany them. As the Darfur crisis has shown, financial and institutional incapacity exacerbates the problems for the AU to implement the right to intervene in a Member State. The challenge therefore is to weigh the legal norms of state sovereignty, non-intervention and non-use of force against the duty for collective action to protect human rights.

The framers of the UN Charter did not discuss whether humanitarian intervention had been previously allowed under customary international law or would be permissible or prohibited under the Charter (Lepard 2002:334). Despite its origins in ethical principles, the doctrine of humanitarian intervention has crystallised from a principle of 'pure morality' into a legal principle. Therefore, rather than seek guidance on relevant ethical principles in a particular philosophy, an evaluation of the merits of humanitarian intervention needs to be juxtaposed against the UN Charter and contemporary international law. As a guidepost, the focus should be on the prohibition of force in international law and the twin principles of non-intervention and state sovereignty under the UN Charter. In this connection, the threshold question relates to the normative status of the right of intervention by the AU. Therefore, this article examines the applicability of the right to intervene by the AU in Article 4(h) against the background of the UN Charter.

\section{Enforcement by consent: The congruence of Article 4(h) of the AU Act and the responsibility to protect}

In light of their colonial experiences, many African and Asian countries have been sceptical about Western justifications for intervention, and thus these states are less inclined to view intervention as legitimate, even if it is meant to stop grave human rights abuses. Together with Russia and China, the States from the Southern hemisphere have insisted on UN authorisation as a prerequisite for intervention. Given the importance attached to their sovereignty by the relatively young African States, most of which became independent in the 


\section{The end of humanitarian intervention}

process of decolonisation after World War II, their recent emphasis on the notion of sovereignty as responsibility' (Deng 1993) and the concomitant policy of non-indifference (Kioko 2003:817) is a quantum leap towards the prevention of serious human rights violations. Given the experience with mass atrocity crimes on the continent, the posture of collective enforcement action with or without authorisation of the UN is easy to explain. This point is strengthened by the OAU Secretary-General's report which recommended that given the failure of the UN to forestall conflicts in Africa and the robust intervention provisions in the AU Act, the mandate of the OAU Mechanism for Conflict Prevention, Management and Resolution should be enlarged to provide for deployment of peacekeeping forces and peace enforcement in circumstances provided in Article 4(h) and (j) of the AU Act (Levitt 2003:115).

The UN General Assembly too has endorsed this emerging norm in its 2005 World Summit Outcome document. As UN Members, AU States have also unanimously endorsed that in the face of mass atrocity crimes the international community has a responsibility to protect $(\mathrm{R} 2 \mathrm{P})$ the population, be it with a State's consent or not. Given this experience, it is obvious that implementing the right to intervene and putting the concept of $\mathrm{R} 2 \mathrm{P}$ into practice should be at the heart of African legal, political and decision-making machinery. A 'sense of shame at the passivity of the international response' has been hugely important to the evolution of the $\mathrm{AU}$ right of intervention with the resultant political commitment of R2P (Williams 2007:23). The inaction of the Security Council in Rwanda in 1994, the codification of enforcement by consent in Article 4(h) is a milestone in the protection of human rights in Africa as the AU may be seen to surmount the potential impasse in the Security Council, towards an independent mechanism to respond to crises in Africa. Rather than a revolution, it is an evolution, because the $\mathrm{AU}$ has overturned the non-interference principle of its predecessor the OAU, and declared that Africans can no longer be 'indifferent' to mass atrocity crimes on the continent. In this way, claims of sovereignty cannot be a shield against multilateral enforcement action under Article 4(h) of the AU Act.

Although Article 53 (1) of the UN Charter requires that any enforcement action by a regional body should have authorisation, the AU establishment of a 'right' 
of intervention is by consent. States party to the AU Act legally acknowledge the existence of this right, and create a series of representative institutions designed to give it force. It is also necessarily multilateral. No particular state is endowed with the right to intervene. Rather, this right is conferred upon the AU itself, pursuant to a decision by the Assembly of Heads of State. However, Article 103 of the Charter invalidates any treaty obligation that conflicts with obligations of UN Member States under the UN Charter. However, a case can be made that Article 4(h) constitutes enforcement action by consent to prevent or halt mass atrocity crimes, an obligation which seems to be outside the scope of Articles 53 and 103. The reasoning being that the obligation under Article 4(h) is not in conflict with obligations under the UN Charter. In addition, while Article 53 does not say whether authorisation can be prior to or after the fact, the UN Security Council has a practice of giving post facto endorsement to sub-regional organisations such as ECOWAS in Liberia and Sierra Leone in the 1990s. However, this is not to say the enforcement action under Article 4(h) does not require Security Council authorisation.

Today, the doctrine of state sovereignty must be interpreted in the context of the changing value systems of the international community, whereby sovereignty is increasingly viewed as hinging on a state's responsibility to protect its citizens and that failure by a state to do so automatically invites intervention by the community of States in various forms, including forcible military intervention. Sovereign rights should be dependent upon the protection of minimum standards of common humanity. The normative basis of R2P lies in the obligation inherent in the concept of state sovereignty itself; the responsibility of the UN Security Council under Article 24 of the UN Charter to maintain international peace and security; specific legal obligations under human rights and international humanitarian law, national law; and, developing state practice, and the practice of the UN Security Council itself (Kindiki 2007:vi; ICISS 2001:xi). The norms underpinning the AU's right to intervene reflect the elements of the protection framework embodied in the principle of R2P. From another angle, by endorsing the notion of R2P, the world community confirms a trend to protect populations at risk pioneered by the ECOWAS Protocol in Article 25(d) as evidenced by a number of ECOMOG interventions as well as the 


\section{The end of humanitarian intervention}

SADC Protocol. The codification of the right to intervene by the AU confirms a shift from sovereignty as a right to sovereignty as a responsibility. The ICISS Report (2001:8) sets out an elaborate illustration of this paradigm shift:

[S] overeignty implies a dual responsibility: externally - to respect sovereignty of other states, and internally, to respect the dignity and basic rights of all the people within the state. In international human rights covenants, in UN Practice, and in state practice itself, sovereignty is now understood as embracing this dual responsibility. Sovereignty as responsibility has become the minimum contents of good international citizenship.

The consistence of codification of the right of intervention by African States may also be easy to see, considering that it is generally regarded that 'national borders' are regarded as artificial since they were imposed from Berlin in 1883, dividing families, clans, villages, tribes and so forth. African international society is intended to provide international political goods that guarantee the survival, security, identity and integrity of African states, which the majority of African states cannot provide individually' (Jackson \& Rosberg 1982:19). As such its existence assumes a degree of regional awareness and collective identity to the extent that Africa became a 'cognitive region' (Adler 2007:8). Williams (2007:8-9) informs that 'African state leaders and diplomatic elites perceive themselves to be members of an "African" international society based on a degree of shared historical experience and cultural ties'. In this version, 'Africa' is seen as a 'political idea' as well as a 'geographical fact.' 'At its heart', the saying goes, 'was the ideology of African nationalism' (Williams 2007:9, footnote 25). The foregoing argument also derives credence from the Preamble of the AU Act which sets out that the $\mathrm{AU}$ was a practical expression of the dreams of 'generations of pan-Africanists in their determination to promote unity, solidarity and cooperation among the peoples of Africa and African states' and by the desire to tackle the 'multifaceted challenges that confront our continent and peoples in the light of the social, economic and political changes' happening in the world (Sesay 2008:11). This 'general commitment to place people at the centre of political discourse in Africa is backed up by a specific commitment to intervene when people and communities are put in grave danger by the actions or inaction of their own 
governments. The AU Act is the first international agreement to codify a right to intervene in the face of mass atrocity crimes.

Like the incorporation of the AU right to intervene in the AU Act, the general acceptance of R2P by the UN Member States is a quantum leap towards bridging the gap between sovereignty and humanitarian intervention. However, the ambivalent cooperation of the Government of Sudan towards solving the Darfur crisis shows that there is still a gap between this normative commitment and the actual state practice. The challenge is operational, as to how to actually protect civilians from mass atrocity crimes (Mepham \& Ramsbotham 2007:ix). Both the AU right to intervene and R2P, are pro-sovereignty doctrines since they assign high priority to the sovereignty and territorial integrity of its Member States. However, the AU Act places limitations on state sovereignty regarding 'sovereignty as a responsibility'. It is based on the premise that sovereignty is conditional and is defined in terms of a State's willingness and capacity to provide protection to its citizens. Consistent with the duty of all States to fulfil their common and recognised responsibilities under international law, the AU Act obligates its Members to prevent mass atrocity crimes through Article 4(h).

The AU right to intervene is, by and large, on all fours with the notion of R2P. The confluence of both humanitarian streams is shifting the paradigm from sovereignty as a right to sovereignty as a responsibility. Both notions seem to impose an obligation to protect populations from mass atrocity crimes. Puley (2005:12) also notes that both put 'the cardinal emphasis on the overriding importance of prevention'. When all other measures have been exhausted and humanitarian disaster is imminent or underway, both make provision for the use of military force to stop mass atrocities, with or without the consent of the target state. Thus, like the normative commitment of R2P, Article 4(h) acknowledges that the State has the principal responsibility for protecting its citizens from avoidable catastrophe, but when they are unable or unwilling to do so, that responsibility must be borne by the wider community of States, in particular the AU. This view conforms to Judge Alvarez's opinion in the Corfu Channel case (ICJ Reports 1949:43) that sovereignty is no longer absolute but rather an institution which has to be exercised in accordance with international law. According to Stacy (2006:4): 


\section{The end of humanitarian intervention}

National governments must discharge their duty of care towards their citizens, and the 'court' of international opinion passes judgment. The international community acts as proxy for a state's citizens in judging its care for them. If the sovereign fails to treat its citizens, and by that government's own standards, the social contract between the ruler and the ruled collapses, an assessment of the government's failings becomes a tripartite negotiation between sovereign, citizens, and the international community.

Today, sovereignty encompasses both the rights and responsibilities of States and underlies the rights and freedoms of peoples and individuals. With the idea of sovereignty as a responsibility follows ideas that other States could have a responsibility to react to the needs of populations suffering from their own States' failure to act responsibly. The principle of 'sovereignty as a responsibility' connotes that one of the most important functions of governments, and authorities in general, is to uphold the rights and dignity of community members (Lepard 2002:59). Although the UN Charter provides a robust conception of sovereignty, the trust theory of government and its concomitant principle of limited state sovereignty are implicit in evolving norms of international human rights law. According to Article 29(2) of the Universal Declaration, governments are entitled to impose only such limitations on rights 'as are determined by law solely for the purpose of securing due recognition and respect for the rights and freedoms of others and of meeting the just requirements of morality, public order and the general welfare in a democratic society'. This provision implicitly endorses a trust concept of government under which all laws must secure 'due recognition' of the rights of citizens, must be for the benefit of citizens, and must, moreover, be consistent with a democratic society (Stacy 2006:60).

The Security Council can, within the framework of Article 39 of the Charter, 'do away' with the international dimension in situations which involve grave human rights violations (Österdahl 1977:241-271). As Annan (1998:2) has put it, the UN Charter was issued in the name of 'the people, not the governments of the UN. The Charter protects the sovereignty of peoples. It was never meant as a license for governments to trample on human rights and human dignity. Sovereignty 


\section{Dan Kuwali}

implies responsibility, not just power'. This is also evident in other provisions of the Charter, such as Article 3, affirming that 'everyone has the right to life, liberty and the security of person'; Article 55 that commits the UN to 'promote [...] universal respect for, and observance of, human rights and fundamental freedoms'; and Article 56 that pledges all Members 'to take joint and separate action' toward this end. Further affirmations of the responsibilities of sovereignty are manifested in the Genocide Convention, the Universal Declaration of Human Rights, and other international covenants that make no distinction on whether the offender is a foreign invader or one's own government.

Despite normative movement from 'non-intervention' to 'non-indifference' and the corresponding concept of 'sovereignty as responsibility', there is fear that could potentially allow powerful States to intervene in countries without a clear legal mandate (Centre for Conflict Resolution 2005:27). However, the AU has reaffirmed that the use of force should comply with the provisions of Article 51 of the UN Charter which authorises the use of force only in cases of legitimate self-defence. This concern, however, raises the need for clear-cut criteria for intervention. Indeed, most third world countries, many of them African States, abhorred attempts to expand the notion of intervention at the cost of sovereignty for fear that it would be reserved for the most powerful States. Now it is the African States themselves expressing that state sovereignty cannot be total in the sense that States can do whatever they want with their citizens without regard to the interest of other States. By incorporating the right of intervention in the AU Act, the AU States consented that sovereignty carries with it the responsibility of States to provide for the security and well-being of those residing on their territories. Notably, the preceding Article, $4(\mathrm{~g})$ of the AU Act, establishes the principle of '[n] on interference by any Member State in the internal affairs of another.' Although these provisions may initially appear contradictory, Puley (2005:9) is of the view that 'they are in fact complementary: 4(g) warns against unilateral intervention, while $4(\mathrm{~h})$ provides for a doctrine of non-indifference in the form of multilateral action based on a decision of the Assembly of Heads of State'. Still to be answered is the question of what if the Security Council is unable or unwilling to act as was the Rwanda case. Put differently, the issue is 


\section{The end of humanitarian intervention}

what is the legality of the AU's right to intervene without authorisation of the Security Council due to the use or rather abuse of veto powers.

\subsection{Is authorisation by the $\mathrm{AU}$ authorised authorisation for intervention under Article 4(h)?}

The Security Council has a legal right to authorise humanitarian intervention under Chapter VII of the UN Charter (Wheeler 2004; Bellamy 2005:33). Although it is sometimes argued that there is a moral right to intervene without council authorisation in extreme cases, the issue of a 'moral right' is of no concern for lawyers in view of the positive law of the UN Charter. The issue that has been subject of the differences in the crystallisation of the notion of R2P is the question as to what if the Security Council is unable or unwilling to act. The International Commission on Intervention and State Sovereignty (ICISS) left open whether and under what circumstances an intervention not authorised by the Security Council or the General Assembly would be valid from a positive law perspective. While there is consensus that intervention on the part of regional organisations should be under UN authorisation, both the AU Act and the Peace and Security Council (PSC) Protocol are silent on what will happen if the UN will not authorise intervention. The Ezulwini Consensus, however, gives guidance that such approval could be granted 'after the fact' in circumstances requiring 'immediate action' (AU 2005). However, intervention not authorised by the UN Security Council is 'action under risk'. If other States generally accept that there was a valid case for humanitarian intervention, the action will be condoned $e x$ post by way of acquiescence. Its legality remains pending and has to be determined conclusively at a later stage. It may be regularised post hoc (or not) according to the reactions of the international community (Kolb 2003:133-134).

Authorisation by the UN Security Council has important legal and practical consequences. The solid foundation of the non-intervention rule has been a concern about States acting unilaterally, pursuing their own interests, dominating other societies, and getting into wars of aggression with each other (Roberts 2000:37). The AU Act has clearly outlawed such unilateral intervention 'by any Member State in the internal affairs of another' in Article 4(g). The AU Act has spelt out the conditions for first-tier intervention in Article 4(h) as 
being serious international crimes that are subject to universal jurisdiction. It follows, therefore, that if an intervention is authorised by such a regional body, and has specific stated purposes, the concern for ulterior motives in unilateral interventions would seem to fade (Roberts 2000:37). Therefore, if a regional body such as the AU provides legitimation for intervention pursuant to Article 4(h) without authorisation of the Security Council, it is not necessarily because of the Charter provisions about regional arrangements under Articles 52 and 53 of the UN Charter, but because strong regional support for an intervention under Article 4(h) would be evidence, albeit not conclusive proof, that it represents a legitimate cause (Roberts 2000:39).

It appears correct to contend that by consenting to Article 4(h) of the AU Act, AU States have transferred a certain part of their sovereignty to the supranational organ the AU. While the prohibition of the use of force has the status of jus cogens and thus cannot be contracted out by States, AU States waived their right to be free from intervention by the $\mathrm{AU}$ as a multilateral body in the face of mass atrocity crimes. Kunschak (2006:207) argues that Article 4(h) can be interpreted as a general a priori invitation to intervene to stop mass atrocities. Thus, AU States agreed in advance that the AU is entitled to help them, should a situation of genocide, war crimes or crimes against humanity arise. This acceptance implies a shift from sovereignty as a right to sovereignty as a responsibility. It follows that a government that seriously violates its duties towards its citizens loses its representative function and may not object to such intervention. The rationale is that it is not the abusing governments that are protected, but the citizens.

\subsection{The conundrums of conditions for intervention under Article 4(h) of the AU Act}

The conditions for intervention under Article 4(h) of the AU Act are mass atrocity crimes, namely, war crimes, genocide and crimes against humanity. These thresholds imply that not all violations of international human rights and humanitarian law could justify AU intervention. It is easy to notice that intervention under Article 4(h) is activated not only because the thresholds are serious crimes internationally punishable but also because the crimes invariably involve a government's action against its own citizens. Roberts (2000:21) informs 


\section{The end of humanitarian intervention}

that 'the slaughter by a government of its own populations cannot be allowed to go unpunished because of an excessive deference to the idea of sovereignty'. Such intervention is justified largely in terms of saving lives that might otherwise be lost. As such, the rationale for intervention must depend crucially, not on actual crimes or hard numbers, but the culpability of the national government in either causing or tolerating such mass atrocity crimes. Under what Stacy (2006:6) calls the 'theory of relational sovereignty', extreme harm to citizens is evidence that sovereignty is no longer an absolute shield against international intervention (Stacy 2006:6).

Article 7(1) (e) of the PSC Protocol informs that the PSC shall recommend to the AU Assembly, intervention in a Member State in respect of 'grave circumstances' under Article 4(h) as 'defined in relevant international conventions and instruments'. The AU is bound to adopt the definition of 'war crimes', 'crimes against humanity' and 'genocide', as enshrined in the Rome Statute of the International Criminal Court (ICC), the Genocide Convention, the Geneva Conventions and Additional Protocols or the tried and tested definitions in the Statute of the International Criminal Tribunes of Yugoslavia and Rwanda. However, the lacuna on a common definition of what constitutes genocide or the threshold of 'grave circumstances' involving war crimes and crimes against humanity, may cause paralysis in deciding on intervention under Article 4(h) of the Act. Defining when abuses are 'grave' is highly subjective and the nature of the decision would inevitably be highly politicised. If intervention under Article 4(h) aims at prevention of mass atrocity crimes, it seems contradictory to require 'grave circumstances' before lives are saved. Considering the speed with which mass atrocity crimes occur, the AU should prioritise intervention over legal ascertainment of Article 4 threshold (Abass (2007:52). It is not necessary to prove beyond doubt that war crimes, genocide or crimes against humanity have been committed before action is taken. However, noting that the AU right of intervention is contingent on the existence of these crimes, any intervention taken prior to the requisite assessment will be legally deficient. To overcome such a legal quagmire, the AU may need to broaden the frontiers of the thresholds by viewing them as mass atrocity crimes for purposes of intervention. This view is supported by Scheffer (2007:395-397) who has argued that the generic term 
'mass atrocity crimes' should be used for all policy discussion purposes but that it should be left to the prosecutors and judges, 'to work out which tag is most legally appropriate for a particular case'.

The downside of expanding the interpretation of the thresholds as mass atrocity crimes would add a new meaning to the provisions which the signatory States to the respective conventions prescribing the serious international crimes had not intended. A general formulation would also open up too wide a door for action by outsiders. However, it should be noted that intervention under Article 4(h) does not entail military intervention. More so, it is more accurate today to assert that the creation of a vast body of international human rights law, regulates how States behave towards their citizens, and elevates the protection of human rights as a matter of concern for the international community as a whole. Even the interpretation of the ad hoc tribunals on the thresholds has become more expansive, rather than more restrictive (Akayesu case, ICTR 1998; Kristic Judgment, ICTY 2001). If based on the extent of crimes actually committed or the numbers of casualties, these thresholds fail to take into account the fact that intervention pursuant to R2P, and by extension Article 4(h), has a preventive function. The objective of Intervention under Article 4(h) should be to prevent mass atrocity crimes. As such, the rationale for intervention must depend not on actual crimes or hard numbers but the culpability of local authorities in such crimes as well as their inability to uphold legal order (Stacy 2003:6).

\subsection{Deterrence: The missing link between $\mathrm{AU}$ intervention and universal jurisdiction}

The way to apprehend and punish the perpetrators of mass atrocity crimes is through an international legal framework that establishes the notion of universal jurisdiction. In Pinochet (No. 3), Lord Phillips didactically reasoned that 'the exercise of extra-territorial jurisdiction overrides the principle that one State will not intervene in the internal affairs of another'. His Lordship was of the view that ' $[a] n$ international crime is offensive, if not more offensive to the international community when committed under colour of office' ([1999] 1 AC 147:289). Such international crimes are subject to extra-territorial jurisdiction because each State is deemed to have a common interest in the international legal 


\section{The end of humanitarian intervention}

and social order and in international peace and security. Where public officials perpetrate serious international crimes, the arguments for upholding immunity are weak. In such cases, the arguments for universal criminal jurisdiction as a less invasive form of humanitarian intervention may be compelling. The pragmatic rationale for universal jurisdiction is justified where the perpetrators of the crimes would otherwise go unpunished. In R. v. Finta, Judge La Forest held that the extraterritorial prosecution of war crimes and crimes against humanity was of 'practical necessity' because the central concern is state-sponsored or sanctioned persecution and, in such cases, the state is unlikely to prosecute and the perpetrators are often dispersed or exiled ([1944] 1SCR, p. 701). This applies to the crime of genocide.

Nonetheless, universal jurisdiction does not seem to be purely preventive given that it cannot normally be exercised before any crimes have been committed. It would thus be principally a responsive measure. The anchor of the notion of $\mathrm{R} 2 \mathrm{P}$ is the responsibility to prevention which rests upon the firm legal foundation grounded in the international human rights and humanitarian law treaties. Likewise, the goal of the right to intervene by the AU should be to prevent mass atrocity crimes. In the Bosnia and Herzegovina v. Serbia judgment, the International Court of Justice (2007) firmly established that the Genocide Convention, which is a peremptory norm of international law, requires under certain circumstances that States act to prevent genocide even outside their own border. Similarly, the 1949 Geneva Conventions assign collective responsibility to all States Parties to the Conventions for ensuring compliance with their provisions to ensure that international humanitarian law is respected in all circumstances'. This principle is embodied in Article 1 common to the Geneva Conventions and is considered to be customary law.

The key to addressing this problem lies in reconciling intervention and universal jurisdiction in order to appreciate their potency, not simply as reactive or remedial legal devises, but to deter potential perpetrators. The AU right of intervention and universal jurisdiction have the potential to give deterrence credibility and validity. If the possibility of prosecution makes potential perpetrators less likely to commit mass atrocity crimes that is deterrence. Article 4(h) in its present formulation seems to suggest that intervention will occur upon the commission 
of war crimes, genocide and crimes against humanity. This reactive theory is not in line with the preventive agenda in the protection of human rights. It is for this reason that the AU needs to link the intervention under Article 4(h) to Article 4(o) of the AU Act which provides for ending impunity. Institutionalising deterrence is perhaps one of the most effective ways to give meaning to the right of intervention under Article 4(h). As such, there is need to align the AU right to intervene to bring it into congruence with the extant legal paradigms of sovereignty as a responsibility and universal jurisdiction for such crimes that are invariably committed with the complicity of states.

\section{Conclusion - From humanitarian intervention to statutory intervention}

The provision of the right to intervene under the AU Act is not only a stark departure from the traditional notions of the principle of non-interference and non-intervention in the territorial integrity of nation States but it is also in sharp contrast with the long-standing principle of state sovereignty. Through Article 4(h), the AU created a regional normative framework for sovereignty as a responsibility congruent to $\mathrm{R} 2 \mathrm{P}$ as embraced by the World Summit Outcome Document (UN 2005:para 138-139). The consensus endorsement of the R2P reoriented the debate on humanitarian intervention by focusing on the responsibilities of individual States and, if necessary, the UN and its Member States. The notion of R2P falls squarely within the objective of Article 4 (h) of the AU Act which is intended to protect populations facing mass atrocity crimes.

Going by Article 4(h), the contemporary view in Africa is that of protection of human rights from mass atrocity crimes, rather than state sovereignty. This explains the endorsement of the statutory right to intervene in a Member State by the supranational body, the AU. Given the prevalent mass atrocity crimes in Africa, Article 4(h) of the AU provides additional instruments to protect human rights and humanitarian norms on the continent. The AU is a trailblazer in this regard by introducing enforcement by consent in the form of the right to intervene in Article 4(h). Article 4(h) may be seen as a complement 


\section{The end of humanitarian intervention}

and a valuable contribution, not a substitute for the existing structures and instruments obtaining under the UN Charter. In this case, Article 4(h) offers a wider menu of legal options to respond to mass atrocity crimes which is selfevidently essential. However, financial and institutional incapacity stand in the way (Levitt 2003:122).

Yet to be answered is how to reconcile the right to intervene under the AU Act with the UN Charter. Article 4(h) of the AU Act can be interpreted as a general a priori invitation to intervene in the face of mass atrocity crimes. While the Security Council remains the bedrock of international peace and security, the AU has a ready, steady and wide range of military and civilian options to timely respond to crises in Africa. The AU right to intervene under Article 4(h) can and should co-exist with the Security Council's primary responsibility for the maintenance of international peace and security in Article 24 of the UN Charter. The merit of this view is derived from the AU's PSC Protocol which articulates that the UN has the primary responsibility for maintaining international peace and security, but it also notes that the AU has the primary responsibility for peace, security and stability in Africa. As a consequence, when a State cannot accept the help from competent external organs to protect its citizens, it will ultimately be held accountable without being able to invoke Article 2(7) of the UN Charter. The AU was created in accordance with the principles of the UN Charter and it recognises the primary responsibility of the Security Council for maintaining peace and international security under Article 24 of the UN Charter. The obligations prohibiting the mass atrocity crimes in Article 4(h) are held to the international community as a whole and not only to individual states. The right to intervene under Article 4(h) is laid down in a multilateral treaty, and as such firmly rooted in consensualism.

The AU right to intervene is a useful mechanism to fill critical gaps in the UN's human security protection regime on the African continent. The AU right of intervention can be seen as an increase in the range of instruments available to African States for responding to crises in Africa (Banda 2007:21). By incorporating Article 4(h), AU States sacrificed their autonomy as far as ending mass atrocity crimes is concerned. African leaders have consciously and willingly contracted away sovereignty for greater aspirations of protection of population at risk of 
war crimes, genocide and crimes against humanity. While it is true to say that sovereignty can no longer be used as an excuse for not addressing mass atrocity crimes, this understanding of the limits of sovereignty does not necessarily warrant armed intervention. The goal of protective intervention under Article $4(\mathrm{~h})$ is not to wage war on the target State in order to destroy it and eliminate its statehood, but to protect populations from mass atrocity crimes. Article 4(h) was adopted with the sole purpose of enabling the AU to resolve conflicts more effectively on the continent (Kioko 203:817). A functioning AU should not be viewed as a replacement for, but as complementary to, the UN and the international community in fulfilling their responsibility to protect populations at risk of mass atrocity crimes (Ekiyor 2007:6).

Article 4(h) gives the AU a strong legal basis for intervention in the face of mass atrocity crimes. This is statutory intervention, which removes the need to justify intervention on moral and ethical grounds, i.e., the end of 'humanitarian' intervention. The AU right to intervene cannot be viewed as a euphemism for humanitarian intervention but as a normative commitment of AU States to prevent mass atrocity crimes on the continent. By consenting to Article 4(h), AU States understood themselves to be granting a responsibility to the AU and the international community to intervene where a Member State is unable or unwilling to undertake to protect its population from mass atrocity crimes. In a quest to avoid a repeat of inaction in Rwanda in 1994, now the legal basis has been laid for the continent to move from a culture of paralysis to a culture of protection. This intervention regime ought to culminate into a culture of prevention and compliance. The conditions for intervention under Article 4(h) are mass atrocity crimes which are subject to universal jurisdiction. The noninterference principle in the internal affairs of States embodied in Article 4(g) is qualified by Article 4(h), since mass atrocity crimes are of legitimate concern to the international community, and give rise to prosecution under the principle of universal jurisdiction.

The AU right to intervene is not just a political slogan but a legal obligation for action by the AU in the face of mass atrocity crimes. The AU has bound itself in advance to an obligation to intervene in prescribed circumstances. As responsible Members, by signing the AU Act with the right to intervene under Article 4(h), 


\section{The end of humanitarian intervention}

AU Member States accepted responsibilities of membership flowing from that signature, as well as a de facto redefinition - from sovereignty as a right of exclusivity to sovereignty as responsibility in both internal functions and external duties. While the host state has the default 'responsibility to protect', a residual 'responsibility to protect' also resides with the broader AU, which is activated when the host state either is unwilling or unable to fulfill its 'responsibility to protect'. The AU right of intervention may be seen as a natural corollary of the extant norm of 'sovereignty as a responsibility', which encompasses the duty of States to uphold human rights and humanitarian norms.

Intervention under Article 4(h) should not be equated with, or be seen through the prism of, military force but rather as a focus on the entire spectrum of preventive strategies. The AU should reduce the need for costly intervention and focus more on dealing with the causes of crisis rather than its symptoms. The AU should focus more on improving human security and promoting rule of law, good governance and economic development in AU States. The challenge for the AU is to develop a political-normative framework that promotes a culture of prevention and a climate of compliance with international obligations. Since the causes of mass atrocity crimes are complex, they need to be addressed in a comprehensive and coherent manner. It is more cost effective to respond when early warning shows that people are vulnerable, than fire-fighting to manage an emergency response. The AU should embrace a calculus of 'persuasive prevention', whose objective is to influence compliance with obligations to prevent mass atrocity crimes (Kuwali 2009). The idea is to stigmatise the commission of such atrocities and ostracise the perpetrators of atrocities considering the institutional, financial and political challenges faced by the AU to implement Article 4(h) and R2P.

\section{Sources}

Abass, A. 2007. The Darfur Crisis: The Role of the African Union in Darfur. Utrecht Journal of International and European Law 24 (65), 47-57.

African Union 2005. The Common African Position on the Proposed Reform of the United Nations: 'The Ezulwini Consensus'. Executive Council 7th Extraordinary Session 7-8 March 2005, Addis Ababa, Ethiopia, Ext/EX.CL/2 (VII) 


\section{Dan Kuwali}

Banda, M. 2007. The Responsibility to Protect: Moving the Agenda Forward. Ottawa: United Nations Association in Canada.

Bellamy, A.J. 2005. Responsibility to Protect or Trojan Horse? The Crisis in Darfur and Humanitarian Intervention after Iraq. Ethics \& International Affairs 19 (2), 31-54.

Cassese, A. 1999. Ex iniura ius oritur: Are We Moving Towards International Legitimation of Forcible Humanitarian Countermeasures in the World Community? European Journal of International Law 10 (1), 23-30.

Centre for Conflict Resolution 2005. A More Secure Continent: African Perspectives on the UN High-Level Panel Report. Seminar Report, Somerset West, Cape Town, 23-24 Apr 2005.

Ekiyor, Thelma 2007. Implementing the Responsibility to Protect Doctrine in Africa. Friedrich Ebert Stiftung Briefing Paper 01. Berlin: Friedrich Ebert Stiftung.

Harhoff, F. 2001. Unauthorised Humanitarian Interventions - Armed Violence in the Name of Humanity? Nordic Journal of International Law 70, 65-119.

ICISS (International Commission on Intervention and State Sovereignty) 2001. The Responsibility to Protect. Ottawa: International Development Research Council.

Jackson, R.H. \& Carl G. Rosberg 1982. Why Africa’s Weak States Persist: The Empirical and the Juridical in Statehood. World Politics 35 (1), 1-24.

Kaplan, R. 2000. Humanitarian Intervention: Which Way Forward? Ethics and International Affairs 17, 23-38.

Kindiki, K. 2007. Intervention to Protect Civilians in Darfur - Legal Dilemmas and Policy Imperatives. Monograph No 131, Institute of Security Studies May 2007. Pretoria: Institute of Security Studies.

Kioko, B. 2003. The right of intervention under the African Union's Constitutive Act: From non-interference to non-intervention. International Review of the Red Cross 852, 807-825.

Kolb, R. 2003. A Note on Humanitarian Intervention. International Review of the Red Cross 849, 119-134.

Kunschak, M. 2006. The African Union and the Right to Intervention: Is There a Need for UN Security Council Authorisation? South African Yearbook of International Law 31, 195-208.

Kuwali, D. 2009. Persuasive Prevention? - A Calculus for the Implementation of the AU Right to Intervene and the Responsibility to Protect in the Context of the UN Charter. Lund: Lund University Press.

Lepard, B. 2002. Rethinking Humanitarian Intervention - A fresh Legal Approach Based on Fundamental Ethical Principles in International Law and World Religions. University Park: Pennsylvania State University Press.

Levitt, J.I. 2003. The Peace and Security Council of the African Union: The Known Unknowns. Transnational Law \& Contemporary Problems 13, 109-137.

Mepham, D. \& A. Ramsbotham 2007. Safeguarding Civilians - Delivering on the Responsibility to Protect in Africa. London: Institute of Policy Research. 


\section{The end of humanitarian intervention}

Powell, K \& S. Baranyi 2005. Delivering on the Responsibility to Protect in Africa. Policy Brief, North South Institute. Available at <www.nsi-ins.ca/english/pdf/responsibility_protect_ africa.pdf>

Puley, G. 2005. The Responsibility to Protect: East, West, and Southern African Perspectives on Preventing and Responding to Humanitarian Crises. Working Paper, Project Ploughshares 05-5 (2005).

Roberts, A. 1993. Humanitarian War: Military Intervention and Human Rights. International Affairs 69 (3).

Sesay, A. 2008. The African Union: Forward March or About Face-Turn? Claude Ake Memorial Papers No. 3. Uppsala: Nordic Africa Institute.

Scheffer, D. 2003. Genocide and Atrocity Crimes. Genocide Studies and Prevention 1 (3).

Stacy, H. 2006. Humanitarian Intervention and Relational Sovereignty. Stanford Journal of International Relations. Available at $<$ http://sjir.stanford.edu/7.7.1.06_stacy.html $>$

Sunga, L.S. 2006. The Role of Humanitarian Intervention in International Peace and Security: Guarantee or Threat? In: Hans Köchler (ed), The Use of Force in International Relations: Challenges to Collective Security. Vienna: International Progress Organization.

Wheeler, N.J. 2004. The Humanitarian Responsibilities of Sovereignty: Explaining the Development of a New Norm of Military Intervention for Humanitarian Purposes in International Society. In: Jennifer M.Welsh (ed), Humanitarian Intervention and International Relations, 32-41. Oxford: Oxford University Press.

Williams, P.D. 2007. From Non-Intervention to Non-Indifference: The Origins and Development of the African Union's Security Culture. African Affairs 106 (423), 1-27.

\section{Cases}

Case Concerning the Application of the Convention on the Prevention and Punishment of the Crime of Genocide (Bosnia and Herzegovina v. Serbia and Montenegro case), 26 February 2007, ICJ Judgment, General List No. 9

Corfu Channel case, ICJ Reports 1949, 43

Finta case, [1994]1 RCS, P. 814.

Prosecutor v. Jean-Paul Akayesu, Judgment, Trial Chamber I, 2 September 1998.

Prosecutor v. Kristic, Case no. IT-98-33-T, Judgment (2 August 2001).

R. v. Bow Street Metropolitan Stipendiary Magistrates Court and Others, ex parte Pinochet Ugarte (No. 3) [1999] 2 ALL ER 97. 
